\title{
Sociabilities and sensitivities: \\ recruitments in homeless animal care
}

\author{
Andréa Osório \\ Instituto de Ciências da Sociedade de Macaé, Departamento de Contabilidade, \\ Universidade Federal Fluminense, Niterói/RJ, Brazil.
}

\begin{abstract}
Abastract
Homeless animal protectors are volunteers who rescue, care for and donate abandoned animals for human adoption. They make up networks, organizing themselves into groups or acting autonomously. Interviews with protectors in the State of Rio de Janeiro, Brazil, afford an understanding of the recruitment system in these networks and activities. The collected stories are compared to similar processes observed by other studies of the field, especially in relation to animal rights movements. Recruitment was found to be associated with Veterinary Medicine schools and sociability networks, but self-recruitment cases via the internet, especially via Facebook, were also observed.
\end{abstract}

Key words: animal protectors; sociotechnical network; activist recruitment; animal welfare.

\section{Sociabilidades e sensibilidades:}

\section{Recrutamentos na proteção a animais de rua}

\section{Resumo}

Protetores de animais de rua são voluntários que resgatam, cuidam e encaminham para adoção humana animais em situação de abandono. Integram redes de proteção, organizam-se como grupos ou agem de forma autônoma. Entrevistas com protetores fluminenses permitiram uma compreensão do sistema de recrutamentos nessas redes e atividades. As narrativas colhidas são comparadas com processos similares observados na literatura da área, com ênfase para o movimento pelos direitos dos animais. Verificou-se recrutamentos relacionados aos cursos de medicina veterinária e a redes de sociabilidade, bem como autorecrutamentos através da internet, especialmente através do Facebook.

Palavras-chave: protetores; redes sociotécnicas; recrutamento de ativistas; bem-estar animal. 


\title{
Sociabilities and sensitivities:
}

\section{recruitments in homeless animal care}

\author{
Andréa Osório
}

\section{Introduction}

Several recent studies exist about pets in the Brazilian urban context (Oliveira 2006; Osório 2011, 2013; Bevilaqua 2011; Segata 2012, 2013, 2015; Lewgoy \& Sordi 2012; Pastori 2012; Matos 2012; Pastori \& Matos 2015). A few of these works set out to analyze homeless animal protectors, including the texts by Osório (2011, 2013), Matos (2012), Santos (2014) and Lewgoy, Sordi \& Pinto (2015). None of them, however, develops a more sustained analysis of the process through which someone begins to see her or himself as a protector. In order to better understand this involvement in street animal protection actions in contemporary Brazil, nineteen women and one man were interviewed in the State of Rio de Janeiro, southeastern Brazil. ${ }^{1}$ The interviews were conducted in 2013 and 2014 and were focused in Greater Rio de Janeiro and along the northern coast of Rio de Janeiro State (the cities of Macaé and Rio das Ostras). From these interviews, it was possible to generate a profile of these protectors, their actions, motivations and reasoning.

This article explores the recruitment and self-recruitment processes in animal ${ }^{2}$ protection networks, visible in the ten interviews selected. These processes are developed along two axes: the first linked to sociability networks, which include Veterinary Medicine graduation courses, animal shelters and neighborhood networks; and the second related to the internet, particularly to Facebook, where selfrecruitment is common. Facebook is a tool whose very structure allows the creation of social networks. Thus, it is interesting to observe that the site has enabled some interviewees to find other protectors online and, as a result, build new social connections, even though some of the interviewees had already been actively working as protectors, differently from those recruited in face-to-face interactions. The recruitment or self-recruitment of the other ten interviewees is not visible in their narratives and will be analyzed later.

The article presents a brief socioeconomic profile of each of the interviewees, though only ten reports will be considered for the purposes of the present analysis. The general profile of the interviewees indicates that animal protectors are typically white, middle class and female. This finding is also reported in American studies on protectors (Zasloff \& Hart 1998; Neumann 2010) and on animal rights activists (Herzog Betchart \& Pittman 1991; Herzog 2007; Gaarder 2011).

A brief theoretical remark on recruitment and self-recruitment in animal rights movements needs to be made prior to discussing the ten interviewees focused on here. The reports were divided into three groups: a) interviewees who study or have studied Veterinary Medicine; b) interviewees recruited by neighborhoodrelated sociability networks; c) self-recruited volunteers who found a protection network via the internet. The integration of the protectors into sociotechnical networks (Latour 2001) is clearly perceptible in group A and group C. Because of the lack of a suitable alternate term, use of the word network may appear somewhat ambiguous. For the purposes of this article, the term mainly refers to relations of sociability, except where explicit reference to the Latourian concept is made.

1 Special thanks to Mirila Greicy Bittencourt, awarded an IC FAPERJ scholarship for this research, for her help.

2 Animal here refers to those in an urban context and in most cases does not include animals used in agroindustrial or laboratory activities. Most of the species cited are dogs and cats but may occasionally include chickens, horses, donkeys, mules, pigeons, birds and other pets. 


\section{Socioeconomic profile}

Six of the nineteen women interviewed live in Rio das Ostras, ${ }^{3}$ one in Niterói, ${ }^{4}$ one in Cabo Frio, ${ }^{5}$ one in Macaé 6 and ten in Rio de Janeiro. The latter live in the northern and western regions of the city, in not so well-off neighborhoods. Six of them are under 35 years old, nine are between 40 and 49 and four are 50 or older. The youngest are 22 years old and the oldest 71 . Ten women declared themselves white, three mixed descent and four black. Two of the interviewees did not declare their ethnicity/race. Eight are single, ten married and one is a widow. Six of them have children, all of whom are married or widowed: one of them was pregnant at the time of the interview, the other women had children between the ages of 17 and 26. Only one of the protectors had younger children. Four of the women lived alone, one of whom declared herself married. The others live with their parents, siblings, children and/or husband.

The professions declared by the interviewees range from housewife to university teaching positions. Five of the women do not have paid jobs: two are housewives, one is retired, one is a college student and one is an unemployed lawyer. Four of them are public servants (a supervisor, a tax analyst, a nurse technician and a secretary), while the others are a flight attendant, an archivist, an administrator, two administrative assistants, a veterinarian, a social worker, a physical therapist, a marketing manager and a protector who declared herself to be self-employed without specifying her business. Eleven of the women are college graduates, including one who is working on a postgraduate degree and another who holds a postgraduate degree. One of them is working on her college degree. Three of the interviewees have technical education, three of them had a high school degree and one of the housewives had just a primary school diploma. One of the technical school graduates and one of the college graduates are studying Veterinary Medicine at university.

In relation to personal and family incomes, a diverse range of situations were observed. The lowest monthly salary, $\mathrm{R} \$ 700$, is earned by a nurse technician whose family income is the second highest: $\mathrm{R} \$ 10,000$. The highest personal income was $\mathrm{R} \$ 11,000$. Family incomes ranged from $\mathrm{R} \$ 2,500$ to $\mathrm{R} \$ 12,000$ per month.

The only man interviewed is 47 years old, single, white, has no kids and lives in Belford Roxo, Greater Rio de Janeiro, with his mother and niece. He has attended high school but has no high school diploma and is not currently studying. He has worked as an educator, industrial cook, artist and salesperson, but does not work at present and lives on a personal income of $\mathrm{R} \$ 800$, reportedly coming from the rental of family properties, which he claims to be the sole family income.

The female prevalence of this sample was a goal at the beginning of the research. From one online identified protector, the research has snowballed into a network of referrals exhibiting a significant female presence, regardless of the researcher's aims. However, this network eventually reached a limit, which was when I decided to include adoption fairs as a strategy to reach animal protectors. Since two of the interviews in the first sample were held in Rio das Ostras, I included the city in the first sample design, which emphasized Greater Rio de Janeiro, as well as Macaé, near to Rio das Ostras. A third adoption fair was visited in Rio de Janeiro and a total of twenty interviews was completed. Just one of these was with a man, reached via the referrals. The essentially female sample undoubtedly raises some gender issues. However,

\footnotetext{
3 Touristic seaside town where a large part of the population works in Macaé.

4 Part of the Greater Rio de Janeiro metropolitan region.

5 Touristic seaside town in the north of Rio de Janeiro state, located in the Região dos Lagos (Lake Region).

6 Centre of the offshore Brazilian oil industry.
} 
the recruitment and involvement processes do not seem to involve any pronounced gender bias, being similar to others described in the specific literature.

No significant differences were found between the socioeconomic profiles of protectors interviewed in the adoption fairs and those of the protectors reached by referrals. Some homogeneity would be expected within the indication system, given that affinity networks are built by people of similar profiles. The most relevant difference refers to age: in the fairs, variation reaches both extremes of the samples, whereas age ranges between 33 and 55 years among the indicated interviewees. The age trend in the referral system may arise from some kind of affinity among the interviewees, which may be linked not just to socioeconomic but also to generational factors. Also, the recurrence of similar profiles in the fairs may indicate a more generalized Fluminense $\mathrm{p}^{7}$ profile.

The concentration of protectors in Rio's North Zone (zona norte) was another tendency uncovered by the research. Factors related to affinity may be involved when it comes to indications, but it has also been observed that protectors prefer to act close to their homes. ${ }^{8}$ Animal abandonment is less perceptible in wealthier urban regions, ${ }^{9}$ hence a smaller contingent of protectors would be expected in more affluent neighborhoods. This is a complex question that merits a more detailed analysis for which I have no space here, as I focus on recruitment processes.

In this analysis I discuss ten interviewees who indicated recruitment processes when questioned about how they became involved in the animal protection world. Their profiles are presented immediately below. All names used are fictitious. Four of the ten interviewees were interviewed at adoption fairs (Amélia, Ângela, Amanda and Cristiane) while the others were reached through referrals. They are presented in their order of appearance in this article.

Amélia, 49 years old, is single, a veterinary doctor, and lives alone in Tijuca, a middle-class neighborhood in Rio's North Zone. No income or ethnicity was declared.

Ângela, 31 years old, white, single, works as a marketing manager, has a college degree and studies Veterinary Medicine. She lives alone in Méier, a middle-class neighborhood in Rio's North Zone. Her monthly income is $\mathrm{R} \$ 4,000$.

Amanda, 22 years old, is white, single, and a student of Veterinary Medicine. She lives with her parents and brother in Tijuca, Rio de Janeiro. No income was declared.

Ana, 46 years old, is married, black, and has a 17 year-old daughter. She lives with her husband, her daughter and her mother in Encantado, a neighborhood in the North Zone. She is a nurse technician and studies Veterinary Medicine. Her family income is $\mathrm{R} \$ 10,000$.

Betânia, 55 years old, white, is married but lives alone in Rio das Ostras. She is a tax analyst with the Brazilian Federal Revenue ${ }^{10}$ and has a college degree. Her income is $\mathrm{R} \$ 11,000$.

Bárbara, 22 years old, white, is single. She lives with her mother in Vila da Penha, a neighborhood in Rio's North Zone. An archivist by profession, she was taking a specialization course when the interview was held. Family income was declared to be over four minimum wages.

Berenice, 43 years old, is single and lives alone in Tijuca, Rio de Janeiro. An administrator with a college education, her income is $\mathrm{R} \$ 5,300$.

Cristiane, 24 years old, is white and single. A recent Law school graduate, she is unemployed and lives with her parents and sister in Cabo Frio. No income was mentioned.

Cássia, 33 years old, white, married, was pregnant at the time of the interview. A flight attendant, she

7 An adjective referring to Rio de Janeiro (State).

8 The Zasloff \& Hart (1998) survey reports that half of the colonies cared for by protectors interviewed in Hawaii (USA) were located close to their homes.

9 For a reflection on animal abandonment zones, see Osório (2013).

10 Equivalent to the IRS in the United States. 
has a college degree and lives with her husband in Curicica, a neighborhood in the west of Rio de Janeiro city. Her family income is $\mathrm{R} \$ 6,000$.

Cecilia, 51 years old, white, married, is an accounting technician but does not perform paid work. She is a housewife and a pensioner. She lives with her husband in Méier, Rio's North Zone. She did not inform her family income, but mentioned that her personal income as a pensioner is $\mathrm{R} \$ 2,900$.

It is noticeable that most of the interviewees are single, with no children, white, college-educated and live in middle-class and lower middle-class neighborhoods in the city of Rio de Janeiro.

\section{Moralities and Sensitivities}

The answers to the questions "what do protectors do?" and "how to define a protector?" complement each other and can be read together": they save lives, respect and help animals, love and defend animals, are sensitive towards animal abandonment, have a 'protecting gift,' sympathize with animal suffering, give animals a decent life, give animals a temporary home, and are educators. Animal protection is conceived as a goal, an activity, a human obligation, a responsibility, an instinct, a need, an occupation, a form of voluntary work, a mission, a way to be loving and considerate towards animal, a gift, a way to be supportive, heartfelt work, a hobby, gratifying, a second job. The protector rescues, collects, cares for, neuters and donates street animals.

Among the answers, we can highlight: 1) an emotional axis, formed by the notions of love, suffering, sensitivity and heart; 2) a moral axis, formed by the notions of mission, obligation, dignity, respect, consideration, responsibility, protection, defense, help, rescue, solidarity and education. Between these axes, some activities (to rescue, care for, protect, donate, work, educate, hobby, second job, occupation) and sensitivities (love, respect, consideration, gratification, solidarity, need, giving) are emphasized. The identity of the protector is connected to what he or she does and their motivations are related to their sensitivities. Some of the interviewees present vocations (Weber 1989), implying that protection appears as a destiny, a mission, a duty in the world.

The responses show a similar relationship between emotion and morality identified by myself (Osório 2011) and Matos (2012) in our research on Brazilian protectors. Both studies indicate that sensitivity towards animal suffering is viewed by protectors as a trigger for protective action, which is seen as a moral obligation and a human responsibility towards animals.

Boltanski (1993) has formulated an analysis of the relation between suffering, pity and morality, focusing on what he calls 'distant suffering.' He argues that watching the suffering of others poses a dilemma to the observer: whether to act or not. If they feel some moral compulsion, they will act. However, he adds that being affected by the suffering of others is not enough to become involved in action. The obligation to help the sufferer is placed both on whoever is causing the suffering and on those who observe it, given that a 'causal responsibility' can arise from action or omission alike.

Put succinctly, Boltanski's (1993) argument applies to situations where action is taken. If suffering does not elicit any action to stop its occurrence, then there is no pity or compassion, only indifference. Street animal protectors are people who never become indifferent to animal suffering, at least at a discursive level. The sight of this suffering produces in them a desire to perform a number of activities, including the rescue of animals - i.e. removing animals from particular situations of suffering. Such action responds to moral imperatives characteristic of this universe.

In the interviews, these moral imperatives emerge in the discourse aligned to sensitivities, i.e., to the

11 Even though the activity-related responses seem to refer to the first question, they were also used to answer the second. 
very perception that the animal is suffering. However, moral imperatives do not always lead to immediate action. We can also note the existence of sensitivities about animal suffering in the interviews, along with the perceived need to take action, but action may derive from factors other than moral imperatives. In other words, indifference may not be the reason for not taking action. In such cases, the involvement in a protection network is what makes action possible for some interviewees, whereas others perform such action spontaneously and autonomously.

\section{Recruitments and the reproduction of social movements}

Within the animal studies literature, the Animal Rights movement attracts more sociological attention than the Animal Welfare movement. This distinction is partly based on the differences in the kinds of action taken by those groups, but also on their different ideologies and their consequences for the lifestyles of their members. The difference between animal welfare and animal rights, putting aside internal differences, is that the first group is a reformist movement which advocates a humanized treatment of animals, whereas the second extends moral preoccupations and Western modern individualist values to non-human animals, considering them inviolable, as well as intrinsically dignified, rightful and valuable (Jacobsson 2014). Or, as Pallota (2005) would say, paraphrasing the animal rights movement itself: some people fight for bigger cages, while others fight for their extinction (abolitionists).

The protectors researched here are situated as people who take part in a diffuse animal welfare ideology, though one of the interviewees cited issues relating to abolitionism. It is possible to detect online connections between groups or individuals involved in animal protection and animal rights movements. To take the interviewees as part of a movement means to include them in a collective process, composed by networks, as I intend to stress in this article. It is not about isolated individuals, therefore, but a network that discusses, spreads news and educates on pet handling, with emphasis on dogs and cats, but occasionally includes other animals in their concerns and on their rescue lists, although in specific contexts. Typical problems in other social movements are also found in the interactions among 'welfarists,' but this article will focus solely on recruitment-related issues.

Gohn (2002) provides possibly the best Brazilian survey of the sociology of social movements. Based on her research, I have pinpointed issues concerning recruitment in social movements. Recruitment is peculiar to the resource mobilization perspective, formed by a number of American authors from the second half of the twentieth century who opposed the previous psychologically centered theories, which viewed collective expressions as a symptom of the irrationality of the masses. The author deems the concept of resources to be the most important variable within this perspective, which includes human resources and ways to retrieve them. In a market composed by social movements and organizations, these are seen to compete among themselves for both physical and human resources. This is where the issue of recruitment becomes visible.

Collective action generates sociological issues related to the involvement of new members in shared interests. The concept of interest, which also has economy-related connotations, is part of the utilitarian model employed by the resource mobilization theory authors. Financial resources include communication channels to reach new members and to make occasional actions possible. A special role belongs to networks built from institutions including, but not limited to, schools, churches, unions and associations. These spaces are identified as relevant in recruitment, as well as in organizing action. Pre-existing networks enhance the power of collective actions.

According to Gohn (2002), resource mobilization theory came under critique and was challenged by a 
distinct reality introduced by the New Social Movement theory, which led to its reformulation as a political mobilization theory. This new version, akin to the European analyses of the New Social Movement theory, has redirected North American analysis towards issues of social psychology, culture and values, and animal rights and animal welfare movements are normally placed within the New Social Movements.

The analysis applied to the interviews with protectors in this study relies strongly on the notions of frame and frame alignment, to which media outlets are a key contemporary instrument insofar as they contribute to the development of collective beliefs. According to Snow et al. (1986: 464):

By frame alignment, we refer to the linkage of individual and SMO [social movement organizations] interpretive orientations, such that some set of individual interests, values and beliefs and SMO activities, goals, and ideology are congruent and complementary. The term 'frame' (and framework) is borrowed from Goffman (1974: 21) to denote 'schemata of interpretation' that enable individuals 'to locate, perceive, identify, and label' occurrences within their life space and the world at large. By rendering events or occurrences meaningful, frames function to organize experience and guide action, whether its nature or intensity. Since we have identified more than one such alignment process, we use the phrase frame alignment process as the cover term for these linkages.

Gamson (1992 apud Gohn 2002) highlights three mobilization components in the frames: injustice, identity and agency. The injustice frame is fairly typical of animal rights and animal welfare movements, and is linked to moral outrage, which acquires a political dimension. However I believe that the other frames are also there to a greater or lesser degree. The agency frame is notable and refers to the possibility of bringing about change through collective action. On the other hand, the identity frame, which refers to the construction of a process of otherness between members of the group and non-members, seems to be more widely present among animal rights activists who embrace a lifestyle change towards veganism. ${ }^{12}$

According to Snow \& Benford (1988, 1992 apud Gohn 2002), the frame is a worldview that should be considered in conjunction with others found in society in order to formulate action strategies. Their concept of frame alignment is equally relevant to the analysis of recruitment issues since it "describes the efforts made by the organizers of a movement to integrate the cognitive orientations of the individuals into those of the movements supporting organization" (Gohn 2002: 88), highlighting the cultural factors that allow someone to adjust to a movement, to be recruited and to take action. Thus, collective actions develop within frame alignment processes.

\section{Forms of recruitment}

In an article comparing two social movements (animal rights and anti-nuclear), Jasper \& Poulsen (1995) analyze the types of recruitment involved in each. Reviewing the literature on the subject, the authors pinpoint the importance of social organizations as triggers to recruitment processes based on sociability networks. In these cases, social organizations and networks build common definitions of the targeted problems and their potential solutions among organizers and potential participants. The frame alignment of new members requires convincing potential members about a problem that needs to be solved (diagnostic), followed by strategies, tactics and appropriate targets (prognostic) and convoking them to engage in these activities (motivation).

However, there is another kind of recruitment, carried out between strangers. For strangers to join a

12 A type of vegetarianism that avoids the consumption of products of animal origin or products whose production involves animal suffering; not only food, but clothing, cosmetics, etc. 
movement where they do not know anyone, Jasper \& Poulsen (1995) observe, they have probably already formed opinions of their own and need no conversion. They are self-recruited. The first step in recruitment by strangers is 'moral shock': "when an event or situation raises such a sense of outrage in people that they become inclined toward political action, even in the absence of a network of contacts" (Jasper \& Poulsen 1995: 498). According to the authors, the shock normally occurs in public and unexpected events. It has the power to draw people to the political organization because it reaches many people and becomes something widely known. The 'moral shock' can also be generated by rhetorical appeal or imagery. By operating as symbols, images can generate an extreme moral appeal in the absence of a sociability recruitment network. For the authors, 'moral shock' not only influences recruitment, it also helps maintain the emotional bond with the social movement. The emotional charge implied in the process has motivational as well as diagnostic elements.

The authors conclude that the mechanisms functioning in the recruitment made by strangers differ from recruitment made by known people. They suggest that social movements try to recruit new members through sociability networks, but these networks will be scarce for new movements, which entail new demands or whose leaders lack extensive previous political experience. However, they add that the period of existence of groups or social movements is not a relevant factor in recruitment patterns. All social movements use both sociability networks and strangers, differing only in proportion.

The internet emerges as a space that has built an extensive network of street animal protectors, bringing together people who used to act alone and independently, and aiding in the construction of a local protection movement where, according to one interviewee, "everyone knows and helps each other." Meeting protectors confers a new meaning to previous experiences of rescuing street animals and gives new momentum to protection activities, which can now go beyond rescue.

The internet seems to work in the analyzed context as a frame alignment mechanism where actual and potential participants "achieve a common definition of a social problem and a common prescription for solving it" (Jasper \& Poulsen 1995: 495). Networks convey meanings, whether we are analyzing recruitment processes through offline networks or by joining online networks. The internet grants access to the networks through self-recruitment, in the sense that the person concerned needs to seek information and the paths forward from the beliefs and values that they have already internalized.

Jasper \& Poulsen (1995) remark that meetings related to animal rights movements they attended involved considerable debate about the problems at hand, including philosophical issues, rather than campaign tactics. The latter, on the other hand, were more frequent in the meetings of anti-nuclear groups where some kind of consensus seemed to exist. My observation of the universe of online street animal protection, focusing on a number of Facebook groups, suggests a massive amount of diagnostic information and relatively little prognostic information. Motivational aspects are even scarcer. In this sense, accounts of online searches for animal protection networks are construed as self-recruitment, not as the result of motivational action performed by online groups.

As observed online, a continuous reproduction of animal suffering that involves specific aspects of 'distant suffering' (Boltanski 1993) is part of the diagnosis and operates as a 'moral shock' factor for this very reason, triggering a strong emotional charge and a moral outrage, serving as a catalyst for potential members. This was not the case, though, for any of the ten interviewees discussed here. All the narratives gathered here point towards a use of Facebook to find a protection network, rather than conversion to street animal protection. In this sense, one might ask whether the online tactic is effective, i.e. does it actually raises awareness among people and does it act as a 'moral shock' factor, aiding in the recruitment of new members, assuming there is an intention to recruit? 
Comparing surveys conducted with anti-nuclear energy activists and animal rights activists, Jasper \& Poulsen (1995) point out that the latter in particular are often recruited outside sociability networks, though 30\% mentioned activism in another social movement. On the other hand, the former were largely recruited from sociability networks. "The symbolic connections between animal protection and other political causes may not be as clear as that between nuclear energy and other issues, so that existing political networks were not available to animal rights organizers" (Jasper \& Poulsen 1995: 501).

In other words, the network of animal rights activists had fewer horizontal connections with other movements and fewer intersections where they could recruit activists from other areas. In the case of the Fluminense interviewees, none were a volunteer in any other network or organization, so this kind of capillary connection would not reach them, but the majority divided between recruitment through sociability networks and self-recruitment via the internet.

\section{Medical sociotechnical networks}

In the four stories presented below, protection activities were started after a recruitment process. Sensitivities formed during childhood can be observed in some of the narratives. Typically, however, there is a discourse of enrollment in an animal protection network. Network is understood here as contacts with other protectors. A significant intersection of such networks with Veterinary Medicine courses, on one hand, and with the internet and particularly Facebook, on the other hand, has been observed, effectively constituting sociotechnical networks (Latour 2001).

Jasper \& Poulsen (1995) emphasize that recruitment through networks is based on the preexistence of social organizations that bring together people with common demands. Recruitment thus occurs through known people. Veterinary Medicine graduation courses seem to be places where an interest in animal welfare can develop, functioning as social organizations from which protectors can be recruited.

Veterinary Medicine not only registers a professional identity, but also sensitivity and a general interest in animals. Veterinary Science is an area of knowledge without which the protection of street animals is impossible. In all the interviews, illnesses and health problems are mentioned as frequent among rescued animals. This situation is not reversed with love alone, as the emotional discourse (Abu-Lughod \& Lutz 1990) of the protectors in their ethics of care (Shapiro 2007) may make it seem. It demands specialized medical interventions as an integral part of this care.

The majority of the 20 interviewees rescue animals on the streets. Only two interviewees manage cat colonies. In most narratives, the same procedures are followed in animal care: removing the animal from the street, normally a dog or a cat, taking it to one's own home or the home of another protector, bathing the animal, removing fleas, deworming, and taking it to the vet for tests, vaccination and neutering. The first procedures are carried out by the protectors themselves, but the last three demand specialized knowledge, exams and medication. In most instances, therefore, an animal is not fit for donation unless it undergoes specific veterinary procedures. Veterinary Medicine acts as a mediator between a homeless animal and a pet animal, therefore, taking part in sociotechnical networks (Latour 2001) which also include the protectors, the animals and adopters.

As Latour (2001) points out, humanity and technology, politics and science, do not oppose each other. Human interaction is sociotechnical, not limited to social bonds or to objects. In the case of protectors, there is technology-mediated interaction with other protectors (via the internet) and science-mediated interaction with the rescued animals (through Veterinary Medicine) which, in turn, generates interactions 
with doctors mediated by animals, which makes veterinarians invisible elements in animal protection. Hence, a rescue or the management of a colony generates a range of more or less visible relations within a large network of participants.

Understanding the influence of sociotechnical networks (Latour 2001) in the engagement and recruitment of protectors involves shifting viewpoint from the moral aspects of protection to a universe marked by science and technology. In this sample, morality and emotion do not vanish from the narratives; rather, new actors and scenarios are incorporated. Protection is no longer a compassion-related issue and acquires a techno-scientific aspect.

Some excerpts of the interviews are cited below:

It started on the Veterinary Medicine [course]. I started to take care of abandoned animals. [...] Since the beginning, really, more than twenty years ago. (Amélia, 49 years old)

Amélia is a veterinarian and one of the longest active protectors among the interviewees. In her story, it is clear that the Veterinary Medicine course has driven her to take action against animal abandonment.

I have cats and I started to study Veterinary Medicine, but before that I already taken care of a cattery, I used to help take run a cattery. Then I was invited to join a [protection] project as a protector. (Ângela, 31 years old)

Ângela is at the intersection of four processes: owning pets, taking care of a cattery (shelter), studying veterinary and actually becoming a protector. Pet ownership is a common element among animal activists. The specialized literature has suggested that owning a pet in childhood is a predisposing factor for empathy towards animal suffering (Pallota 2005; Jacobsson 2014), and that ownership helps develop a caring attitude towards animals (Shapiro 2007). This attitude, Shapiro (2007) underlines, is marked by a continuous sensitivity and capacity of response to their needs. But having a pet can also create this empathy or caring attitude in adults, the author observes.

So, I have always liked animals, [I'm] a vet, right? I started college and then it was through a friend, who said "there's a shelter." So I started there, to learn about the work, right? Then I started to help. (Amanda, 22 years old)

Although recounted briefly, the trajectories of Amanda and Ângela as protectors show similarities with those of some American animal rights activists. Shapiro (2007: 166) suggests that, among the latter, "what begins as a certain sensibility to suffering crystallizes into an avocation - volunteering at the local shelter - then becomes a vocation and, finally, turns into a way of life." The author traces a continuum between the sensitivity to suffering and the activist's lifestyle. In the case of the examined cases, working for shelters appears four times, but I believe that voluntary work with street animal rescue is an analogue within the proposed continuum. Embracing Veterinary Medicine as a profession could be seen within this continuum as the adoption of a lifestyle concerned with animal welfare. Nevertheless, it seems that only a few trajectories obey this formula. Sensitivity, for example, can emerge before or after getting onto a Veterinary Medicine course, as seems to be Amélia's case.

In any case, the author's analysis does not highlight recruitment networks per se and treats callings and conversions to the animal cause as isolated personal events, while other analysts argue that these are in fact shared processes (Jacobsson 2014). According to Weber (1989), the concept of vocation acquires the meaning of destiny, a mission, a duty in the world. Not only are these ideas used by the Fluminense interviewees to define the meaning of animal protection for themselves but, in my view, it makes sense both for protection and veterinary medicine, as far as this intersection is concerned. Ana's story below encapsulates several aspects of the previous narratives: 
So I have always loved animals. The animal protection virus was in my blood because of my father. But, well... I began when my niece, who graduated [in Veterinary Medicine] four or five years ago, in the same place where I study, she would call me: 'auntie, let's go there, you'll love it!' Me? It seems I already sensed that the thing would ensnare me, and I [answered]: 'someday!' Until the day when I went to her graduation ceremony. Man, I'd never enjoyed a graduation so much in my life. There I saw the professors, I saw the joy of their achievement. Man, it really touched me. I said: 'Okay then.' And so it happened. But I already knew [Cecília], I already helped [Cecília] with donations, once in a while, but nothing very intense. (Ana, 46 years old)

The four excerpts are similar in terms of the significance attributed to the Veterinary Medicine course as a milestone in the formation of their identities as protectors. Amélia locates her involvement in animal protection precisely at that moment when she enrolled on the Veterinary Medicine course. Amanda was recruited by a protection network because she was studying Veterinary Medicine. Angela, on the other hand, began to study Veterinary Medicine precisely after becoming involved in a protection network, so too Ana, though the latter mentions different kinds of involvement before and after the course.

Two trajectories exist connecting both activities, then, which do not rule out the notion of an innate identity and of a sensitivity created in childhood, as seen in Ana's narrative about a 'protection virus' contracted from her father. In all the cases, the recruitment of protectors from Veterinary Medicine graduation courses and, on the other hand, the recruitment of veterinarians from among protectors suggests a close link between these activities.

In this sense, animal protection is part of sociotechnical networks (Latour, 2001) where scientific knowledge is essential, but only as a mediator between an abandoned animal and an adoptable animal. Veterinary knowledge is not a priority focus of attention when protectors talk about their activities or try to formulate a definition of animal protection. In such cases, moral and emotional aspects emerge, blurring habitual protective action, which does not only involve tests and appointments with veterinarians and necessary treatments, but the acquisition of a techno-scientific knowledge that can enable the diagnosis of some illnesses before an appointment with a veterinarian, ${ }^{13}$ the interpreting of animal behavior so as to distinguish healthy from sick animals, for example, the introduction of new animals with others already sheltered in a temporary home, and so on.

\section{Neighborhood networks}

Some stories from non-vets follow. In these cases, the emphasis lies on recruitment via neighborhood networks. It is interesting to observe that, here, protectors work near to home. This feature gives a local flavor to the protective actions, so that it preferentially manifests as concrete action to assist the welfare of specific animals located in a particular area.

I have always had animals, more dogs, you see? Some eight years ago, [...] a neighbor asked me to help her neuter a street kitten. This kitten didn't have a home... And I took pity on it. I'd never had a cat before and my idea was to keep the kitten for the postoperative period only. But she never left. [...] Then while wandering in the Maracanã district, ${ }^{14}$ I found other animals that I brought home, you know? So it all began in Rio, sixteen years ago, you see? (Betânia, 55 years old)

Betânia repeats the formula "I’ve always liked/owned animals", which is quite common within this universe. She describes a favor done for a neighbor who was a protector in a quite matter-of-fact way,

13 In general, when there is visibility, as in tumors which become abscesses, venereal tumor in female dogs or sporotrichosis, all of which cause peculiar wounds, among other illnesses.

14 Soccer stadium in the zona norte carioca around which local residents usually hike early in the morning, late in the afternoon and in the evening. 
someone whose animal she adopted, even though the original plan was to give it a temporary home. This event, already marked by sensitivity towards animal suffering, triggers several rescues that make Betânia a protector from her own point of view.

It's... because of community animals. Animals from my condo: cats, cats abandoned in my condo. [...] Yes and another shelter, where I am a volunteer. [...] Because I knew the protector and it's located in the neighborhood near to my house. A poor person who needs help, in short, anyway... (Bárbara, 22 years old).

Bárbara combines responding to the needs of stray animals seen in her condo with actions outside this cat colony, alongside another protector who recruits her to work at a shelter. Again the shelter emerges as a key space within the animal protection universe. It appears as a gateway, as seen earlier, and a way to find a network of protectors and volunteers.

Then I started to see kittens there, you know? There was a man who would give them food, he gave them rice in the evenings. Then I saw [that] sometimes he would give them cat food. So one time the guard, the man who watches over the cars, said 'listen, Mr. José is sick, he is in hospital, he hasn't come today. When you don't come, they [the kittens] are starving.' Because I would only go once in a while, you see? 'They're starving and they're breeding.' Then I became worried and started to bring cat food every night. Then I saw them growing, the cat population growing, because they breed quickly. Then I said: 'no, something must be done. I will start neutering those cats, otherwise I'll spend a fortune on cat food and they'll die soon, they'll get run over, poisoned, I don't know.' So that's what I did. I started to take one, then the other, for neutering. It was a long job, undertaken in tiny steps. Then I started to ask for help. A neighbor saw [what was happening] and came to talk to me. Then other person passed by and said: 'I'll help you, I'll take one here.' Then another person passed by and said: 'T'll help you, I'll take one.' They called the rescue man when the cat was unsociable. So I had them all neutered. There were more than 30 of them. Now there are just 12, because some were adopted, others died, I saw them die, I hospitalized some, some others disappeared. When they disappear, I think they died. Ran over, poisoned, it wouldn't last long, right? And so it went. I used to [perform protective action] only here in the hospital. But protectors are terrible, we hear the animals anywhere. [...] So then I started to rescue them. On the streets, if I pass by and see an animal in these [poor] conditions... not so much adults, though I carry pet food in my bag every day. I feed them when I see them. But puppies or kittens, I rescue them because it's easier for you to treat and donate them. People want younger animals, you know? So I started to rescue them. Then I went onto the internet, started to meet one person here, someone else on the street, everyone started to talk to me, that kind of stuff. It was on the internet that I started to meet protectors. I know a lot of them now, you see? Everyone knows each other, helps each other. (Berenice, 43 years old)

Berenice's recruitment process is slightly different from the previous examples. In fact, she was recruited by a stranger to replace a person who used to feed a cat colony in the parking lot of a hospital close to her residence. Although recruited by a stranger, she did recognize her recruiter. I suggest, therefore, that, although not a protector himself, her recruiter possessed the necessary sensitivity to sympathize with the colony animals and operated as a member of a (local) protection network.

Berenice's occasional activity, which amounted to just feeding the animals, was replaced by intense management: she starts to feed the colony on a regular basis, neuter and medicate the animals, as well as find adopters for them. The experience transforms her into a protector, from her own point of view, and from this turning point (Pallota, 2005) she starts to rescue and feed animals that she finds wandering on the streets. 
In a study of motivations for becoming involved in animal rights movements in the United States, Pallota (2005) found that the appeal to childhood experiences was a recurrent element among her interviewees. The author refers to these situations as predisposing factors. Other factors are situational contingencies and turning points. Turning points may or may not be isolated and datable events, but processes experienced and recalled by the individuals. Predisposition, on the other hand, refers to an internal command present when the turning point occurs, such as childhood experiences and personality traits. Contingencies refer to events that prompt the activist to get in touch with the movement and tend to occur concurrently with the turning point. The latter, in turn, is the key moment when a personal identity transformation and a change in lifestyle happen. It is worth observing that the author refers to activism in animal rights together with the adoption of a vegan lifestyle, i.e., without the consumption of animal products.

\section{Online networks}

In this section I provide excerpts of stories that exemplify the finding of a network of protectors through internet-related mechanisms, with an emphasis on social networks: (the now extinct) Orkut ${ }^{15}$ and Facebook. This kind of recruitment is actually a form of self-recruitment.

My first contact was in this way, because of Macaés fluctuating population, [animal] abandonment is growing and continuous. It drew my attention, and I started adding a lot of protectors on Facebook and it got me involved. I got engaged, then some people started to connect and we assembled this group that's just a protection group. (Cristiane, 24 years old)

Cristiane has a unique history among the interviewees. She does not report having always kept or loved animals, but states that she developed special attention to street animals after moving from her home town to the town where she would attend college. Online social networks, dominated by Facebook's popularity in Brazil, contribute to a self-recruiting process through which Cristiane seeks people who share her concerns. She did not undertake any rescue actions on her own and only became a protector after herself forming a group of people interested in rescuing street animals. Sensitivity and attention towards the living condition of street animals precede her engagement in concrete protection actions.

So, I've always liked [animals]. When I lived with my mother, I used to do something once in a while, like, since I couldn't take one home, I already had two puppies with my mom that I'd taken from the street. [...] I took some more, I had them adopted right away, always among my own family, like 'uncle, do you want a dog?' [laughs]. A bit desperate, you know. But I couldn't do much more than that, because at the time I lived there with her, there was no Facebook, nothing. So I didn't know people who did the same thing I did. Back then I... I thought that I was the only crazy person who wanted to do those things, and that everyone would scold me, right? [...] Then I started to find people through Facebook. [...] I started to help a shelter, go to [adoption] fairs. I took a photography course, so I went with my camera, I took pictures, we spread the news... through Facebook, for adoption and everything. So I started to head in this direction. (Cássia, 33 years old)

Like Cecilia cited below, Cássia reinforces the existence of previous sensitivity: "I have always liked [animals]." Both had pets as children and performed rescue actions before joining a protection network. For both women, this network is important and found online.

15 Orkut appears in Osório's (2011) analysis. 
Listen, I have always... always liked animals. When I was a kid, I was raised at home with animals. [...] And then I grew up, became an adult and had cats in my home. Then the internet came and I started to see the movement. Until then, when I saw some abandoned kitten, I would take it [back home] on my own, take care of it and then donate it. Until that moment, since I live in Méier and there is [the neighborhood square], ${ }^{16}$ you see, it's not my usual route, but one day I passed by the square, it was 2009, and I saw a sea of cats. So I tried to find out what was going on there. It was a huge colony, totally out of control, with procreation, all kinds of diseases. Then I used that tool, the internet, and started to ask for help [...] And with this [virtual] community I managed to... take care of those cats. Donating them, neutering them... treating diseases and reducing the colony's size. (Cecília, 51 years old)

Cecília, along with Berenice, is one of the few interviewees who manages colonies. Cecilia's activity is shaped by her management, which changes the range of her action: occasional rescues are replaced by intense management of nearly seventy animals.

The accounts given by Benedita, Cássia and Cecília are similar. They mix aspects of self-taught or innate protection ${ }^{17}$ and contact with animal protection groups and independent protectors. Facebook has apparently made this contact much easier. Exploiting the popularization of the internet, Cássia publicizes animals for adoption, Cecília "watches the animal protection movement," Cristiane creates a group of protectors, and Berenice meets, helps and is helped by other protectors. All of them seek information on the internet; some of them recruit themselves instead of being recruited.

Cristiane's profile is quite distinct from those of the previous interviewees: she has developed sensitivity and attention towards street animals, but only began to rescue them through the protection group that she helped create. Facebook was a fundamental tool to find a protection network and to raise awareness about the reality of street animals and thereby enable a rescue practice, quite similar to Cássia's case.

Cristiane, Cecília and Berenice report compelling events that can be described as moral shock events (Jasper \& Poulsen 1995). The huge quantity of cats in the neighborhood square, the abandonment in Macaé, the hungry cats in the hospital parking lot: all of these situations required immediate action and woke the interviewees to a reality unknown until that moment, even though some of them report having performed rescues before these events. Hence, it is not about a lack of moral preoccupation or sensitivity, or even absence of action before the moral shock (Jasper \& Poulsen, 1995). Rather, it is about the moral shock acting as a motivational turning point, since it elicits other concrete actions, despite the fact that Cecilia and Berenice had already acted as protectors before managing her colonies. We can perceive how morality and actions combine and how actions can depend not only on sensitivity but also on the entry into sociability networks.

In this sense, some narratives seem to pose a problem of scale. From the occasional care and rescue of animals, protectors turn to the management of colonies, commitment with protection groups and financial donations, etc. The same change in dimension seems to occur when one protector finds other protectors via the internet and realizes that animal abandonment is not limited to their own neighborhood or some area of the city, and that even a large network of activists cannot eradicate the problem.

16 The interviewee asked mention of the exact location to be omitted to avoid new abandonments. Protectors realize that the human population who wants to discard an animal prefers places where other abandoned animals dwell and where there are protectors taking care of them. It is a logic in which abandonment indicates concerns about the well-being of the abandoned animal, as though it were not actually an abandonment after all.

17 As they see it. 


\section{Conclusion}

The paths and setbacks that each interviewee faces as an animal protector involve the emergence of sensitivity toward animal suffering and actions to alleviate it. That sensitivity may be seen by the interviewees as innate or acquired in childhood. It can also derive from living as an adult with pets or near abandoned animals. In all the cases, however, living with animals seems to be a fundamental event in building sensitivity towards their suffering.

As a result, that sensitivity acts as a trigger for concrete actions to alleviate animal suffering as far as abandonment is concerned. While engagement in such actions requires a specific previous sensitivity and morality, that is, an injustice frame (Gamson 1992 apud Gohn 2002), it may also require entry into an animal protection network. Some protectors never act outside of their networks, working only as part of organized groups, like Cristiane, Amanda and Ângela. These groups evoke agency frames (Gamson 1992 apud Gohn 2002), whereas in self-recruitment cases agency exists previously.

Some of the interviewees had already engaged in rescue actions before their self-recruitment into protection networks. The discovery or creation of such networks seem to be due to the popularization of the internet, which made it easier to connect with people with similar interests. The internet not only creates networks, it gives visibility to the problem, since it serves as a means to publicize animals for adoption or rescue: the 'protection movement' becomes visible and donations are collected by protectors in order to fund animal rescue.

A close relationship was also perceived between animal protection and Veterinary Medicine. The veterinarian is a central and invisible figure in animal protection, a person through whom all rescued animals pass, employing a fairly uniform handling procedure judging by the interviewees. According to their accounts, street animals are normally sick, so treatment is the first step in finding a human home. It is no wonder, then, that some of the interviewees became protectors because they were veterinarians, whereas others became veterinarians because of their activities as protectors. The protection analyzed here is inseparable from veterinarian practice.

Finally, I would like to draw attention to protection spaces. Some of the protectors manage colonies, like Berenice and Cecilia. Others are volunteers in animal shelters or catteries, like Amanda, Bárbara and Cássia. Most of them rescue animals from the streets. The protector's space of action is, to some extent, related to the kind of recruitment she has undergone. Shelters and catteries demand involvement in protection networks, whereas colonies and street rescue do not. In all cases, though, it is notable that networks comprise an important element in protection activity.

Translated by Valéria Lima Almeida

Revised by David Rodgers

Received: November 23, 2015, Approved: August 19, 2016 


\section{References}

ABU-LUGHOD, Lila; LUTZ, Catherine A. 199o. "Introduction: emotion, discourse, and the politics of everyday life". In: L. Abu-Lughod; C. A. Lutz (eds.). Language and the politics of emotion. Cambridge: Cambridge University Press. pp. 01-23.

BEVILAQUA, Ciméa. 2011. "Normas jurídicas e agências não-humanas: o caso dos cães 'perigosos". Avá, 19: 199-225.

BOLTANSKI, L. 1993 La souffrance à distance: morale humanitaire, médias et politique. Paris: Métailié.

GAARDER, Emily. 2011. "Where the boys aren't: the predominance of women in animal rights activism". Feminist Formations, 23(2): 54-76.

GAMSON, William A. 1992. Talking politics. Cambridge: Cambridge University Press.

GOFFMAN, Erving. 1974. Frame analysis. Cambridge: Harvard University Press.

GOHN, Maria da Glória. 2002. Teorias dos movimentos sociais: paradigmas contemporâneos. São Paulo: Edições Loyola. $3^{\text {a }}$ ed.

HERZOG, Harold A. 2007. “Gender differences in human-animal interactions: a review”. Anthrozoös, 20(1): $07-21$.

HERZOG, Harold A.; BETCHART, Nancy S.; PITTMAN, Robert B. 1991. "Gender, sex role orientation and attitudes toward animals". Anthrozoös, 4(3): 184-191.

JACOBSSON, Kerstin. 2014. "Elementary forms of religious life in animal rights activism". Culture Unbound, 6: 305-326.

JASPER, James M.; POULSEN, Jane D. 1995. "Recruiting strangers and friends: moral shocks and social networks in animal rights and anti-nuclear protests". Social Problems, 42(4): 493-512.

LATOUR, Bruno. 2001. A esperança de Pandora: ensaios sobre a realidade dos estudos científicos. Bauru: Edusc.

LEWGOY, Bernardo; SORDI, Caetano. 2012. "Devorando a carcaça: contracozinhas e dietas alternativas na alimentação animal”. Anuário Antropológico, 2(1): 159-175.

LEWGOY, B.; SORDI, C., PINTO, L. 2015. "Domesticando o humano para uma antropologia moral da proteção animal”. Ilha, 17(2): 75-100.

MATOS, Liziane Gonçalves de. 2012. Quando a "ajuda é animalitária” - um estudo antropológico sobre sensibilidades e moralidades envolvidas no cuidado e proteção de animais abandonados a partir de Porto Alegre/ RS. Dissertação de Mestrado, Programa de Pós-Graduação em Antropologia Social, Universidade Federal do Rio Grande do Sul - Porto Alegre, RS.

NEUMANN, Sandra L. 2010. "Animal welfare volunteers: who are they and why do they do what they do?". Anthrozoös, 23(4): 351-364.

OLIVEIRA, Samantha Brasil Calmon de. 2006. Sobre homens e cães: um estudo antropológico sobre afetividade, consumo e distinção. Dissertação de Mestrado, Programa de Pós-Graduação em Sociologia e Antropologia, Universidade Federal do Rio de Janeiro - Rio de Janeiro, RJ.

OSÓRIO, Andréa. 2011. "Posse responsável: moral, ciência e educação ambiental em um grupo de protetores de gatos de rua”. R@U - Revista de Antropologia Social dos Alunos do PPGAS-UFSCar, 3(2): 51-75.

OSÓRIO, Andréa. 2013. “A cidade e os animais: da modernização à posse responsável”. Revista Teoria \& Sociedade, 21(1): 143-176.

PALLOTA, Nicole Renee. 2005. Becoming an animal rights activist: an exploration of cultura, socialization, and identity transformation. Diss. PhD, Graduate Faculty, University of Georgia - Athens.

PASTORI, Érica Onzi. 2012. Perto e longe do coração selvagem: um estudo antropológico sobre animais de estimação em Porto Alegre, Rio Grande do Sul. Dissertação de Mestrado, Programa de Pós-Graduação em Antropologia Social, Universidade Federal do Rio Grande do Sul - Porto Alegre, RS. 
PASTORI, Érica Onzi; MATOS, Liziane Gonçalves de. 2015. “Da paixão à ajuda animalitária’' o paradoxo do 'amor incondicional' no cuidado e no abandono de animais de estimação". Caderno Eletrônico de Ciências Sociais, 3(1): 112-132.

SANTOS, Pedro da Silva. 2014. De abandono, proteção e outras formas de relação com animais: motivações, interações e diferenças no Rio de Janeiro e no sertão nordestino. Tese de Doutorado, Programa de PósGraduação em Antropologia, Universidade Federal Fluminense - Niterói, RJ.

SEGATA, Jean. 2012. "Parecidos, o suficiente: nós e os outros humanos, os animais de estimação". R@U Revista de Antropologia Social dos Alunos do PPGAS-UFSCar, 4(1): 207-234.

SEGATA, Jean. 2013. "A agência de um projeto, o paraíso vegetariano e outros inconvenientes com a humanidade dos animais de estimação na antropologia”. Revista Anthropológicas, 24(1): 45-65.

SEGATA, Jean. 2015. "La cosmopolitique de la dépression: biosocialité dans une ethnographie multiespèces”. Vibrant, 12(1): 290-320.

SHAPIRO, Kenneth. 2007. "The caring sleuth: portrait of an animal rights activist (1994)". In: J. Donovan; Carol J. Adams (eds.), The feminist care tradition in animal ethics: a reader. New York: Columbia University Press. pp.153-173.

SNOW, David et al. 1986. "Frame alignment processes, micromobilization, and movement participation". American Sociological Review, 51(4): 464-481.

SNOW, David; BENFORD, Robert. 1988. “Ideology, frame resonance, and participant mobilization”. In: Bert Klandermans; Hanspeter Kriesi; Sidney G. Tarrow (eds.), International social movements research, vol. 1. Greenwich: JAI Press. pp. 197-217.

SNOW, David; BENFORD, Robert. 1992. "Master frames and cycles of protest”. In: Aldon D. Morris; Carol M. Muller (eds.), Frontiers in social movement theory. New Haven: Yale University Press. pp. 133-154. WEBER, Max. 1989. A ética protestante e o espírito do capitalismo. São Paulo: Livraria Pioneira. 6a ed. ZASLOFF, R. Lee; HART, Lynette. 1998. "Attitudes and care practices of cat caretakers in Hawaii”. Anthrozoös, $11(4): 242-248$.

\section{Andréa Osório}

Instituto de Ciências da Sociedade de Macaé, Departamento de Contabilidade, Universidade Federal Fluminense, Niterói/RJ, Brazil.

E-mail: andrea_osorio1@yahoo.com.br 